\section{Fatal food anaphylaxis: a diagnostic dilemma?}

\author{
Elizabeth Mayne (1) 1,2
}

In this case study, Colombo et $a l^{1}$ describe the case of a young woman who develops a fatal anaphylactic response to food. The authors highlight the challenges with postmortem diagnosis of food allergy and anaphylaxis.

Anaphylaxis is an acute and lifethreatening manifestation of a hypersensitivity response. In many, but not all cases, anaphylaxis is a Gell and Coombs classification type 1 reaction mediated by $\operatorname{IgE}$ directed against a specific antigen, ${ }^{2}$ in this context often referred to as an allergen. The severity of anaphylactic responses may be unpredictable and death may occur within minutes of exposure. The cause of death in anaphylaxis may be associated with airway oedema and obstruction.

It may be important in these cases to distinguish the anaphylaxis from other mimetic causes of death (which could include both pathophysiological causes like amniotic fluid embolism or severe asthma as well as exogenous toxins, opioid overdose and traumatic asphyxia) $)^{34}$ also to establish the specific food allergen responsible. A primary effector cell of anaphylaxis is the mast cell which degranulates releasing both preformed and newly formed mediators. These cells may be unstable in the perimortem period. Other key tissue findings associated with anaphylaxis may be present including airway oedema. In the case of fatal food anaphylaxis, causative food compounds may be denatured by

${ }^{1}$ Immunology, University of the Witwatersrand Faculty of Health Sciences, Johannesburg, South Africa ${ }^{2}$ Immunology, National Health Laboratory Service, Johannesburg, South Africa

Correspondence to Dr Elizabeth Mayne, Immunology, University of the Witwatersrand Faculty of Health Sciences, Johannesburg 2000, Gauteng, South Africa; elizabeth.mayne@nhls.ac.za gastric and duodenal digestive enzymes and gastric acid.

The authors emphasise the importance of a multianalytical strategy to confirm fatal food anaphylaxis including measurement of mast cell tryptase, confirmation of presence of food-allergen specific IgE antibodies by a multiplexed immunoassay (the immunoCAP by Thermofisher), confirmation of presence of the allergen in stomach contents and vomitus and histological examination of affected tissues. Mast cell tryptase remains a key indicator of anaphylactic reactions although, in many cases, this may be falsely elevated by perimortem interventions including cardiac massage. ${ }^{3} 4$ In addition, mast cells in the gastrointestinal tract produce less tryptase than mast cells in skin and other tissues and a subsequently lower level of tryptase may be seen in severe food-related anaphylaxis. IgE antibodies are highly specific but may lack sensitivity especially in blood samples taken after death. ${ }^{2}$ With respect to detection of specific food antigens, it is important to extract gastrointestinal contents as soon as possible to prevent irreversible proteolysis and degradation of allergic compounds.

In this case of food-related anaphylaxis, the authors were able to demonstrate high levels of mast cell tryptase combined with histological features of anaphylaxis including airway oedema and eosinophilic airway infiltration. They were able to demonstrate specific IgE against major egg and milk proteins and, most conclusively, were also able to demonstrate the presence within the vomitus and in neutralised stomach contents of quantifiable milk proteins. Further evaluation of samples collected from the restaurant suggested two possible sources for the milk proteins: contaminated creamed vegetables and bruschetta.

Fatal food allergy is uncommon but needs to be identified. This approach emphasises the need for rapid examination in these cases and presents a potential protocol for perimortem diagnostic management.

\section{Handling editor Tahir S Pillay.}

Contributors I am the sole author of this work and was responsible for writing and for the submission of this work.

Funding The author has not declared a specific grant for this research from any funding agency in the public, commercial or not-for-profit sectors.

Competing interests None declared.

Patient consent for publication Not required.

Provenance and peer review Commissioned; internally peer reviewed.

(C) Author(s) (or their employer(s)) 2020. No commercial re-use. See rights and permissions. Published by BMJ.

\section{Check for updates}

To cite Mayne E. J Clin Pathol 2020;73:782.

Received 9 September 2020

Accepted 16 September 2020

Published Online First 15 October 2020

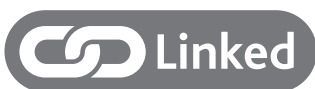

http://dx.doi.org/10.1136/jclinpath-2020-206689

J Clin Pathol 2020;73:782.

doi:10.1136/jclinpath-2020-207083

ORCID iD

Elizabeth Mayne http://orcid.org/0000-0002-63603488

\section{REFERENCES}

1 Colombo F, Restani P, Di Lorenzo C, et al. Sudden anaphylactic death: new insights to identify allergens involved. J Clin Pathol 2020;73:777-80.

2 Beck SC, Wilding T, Buka RJ, et al. Biomarkers in human anaphylaxis: a critical appraisal of current evidence and perspectives. Front Immunol 2019:10:494.

3 Tejedor-Alonso MA, Vallejo-de-Torres G, Escayola EN, et al. Postmortem tryptase cutoff points and main causes of fatal anaphylaxis. J Allergy Clin Immunol Pract 2020;8:761-3.

4 Unkrig S, Hagemeier L, Madea B. Postmortem diagnostics of assumed food anaphylaxis in an unexpected death. Forensic Sci Int 2010;198:e1-4. 